
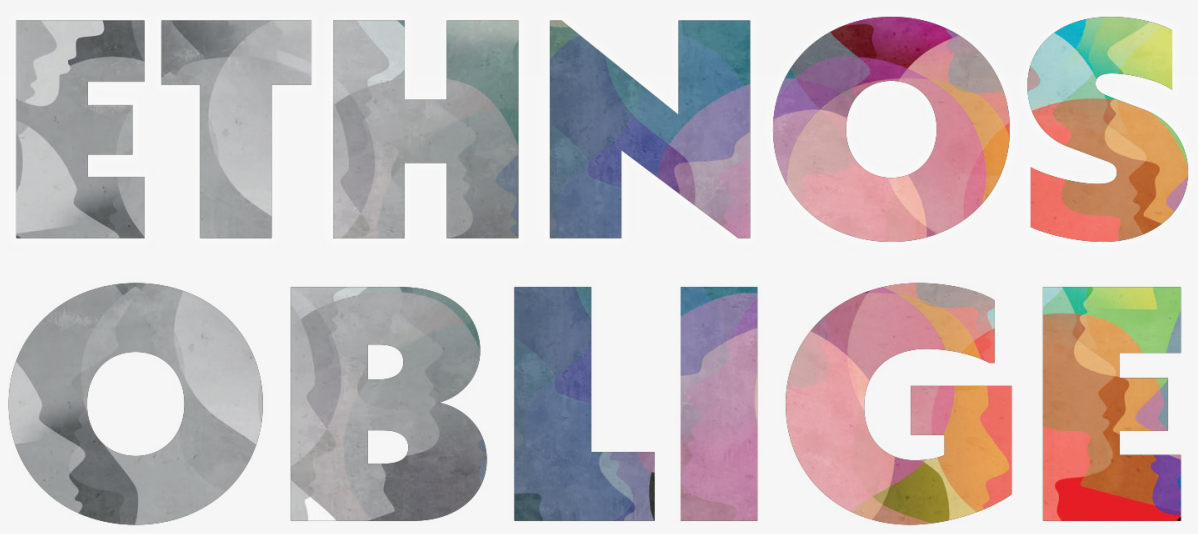

\title{
THEORY AND EVIDENCE
}

BANIYELME D. ZOOGAH

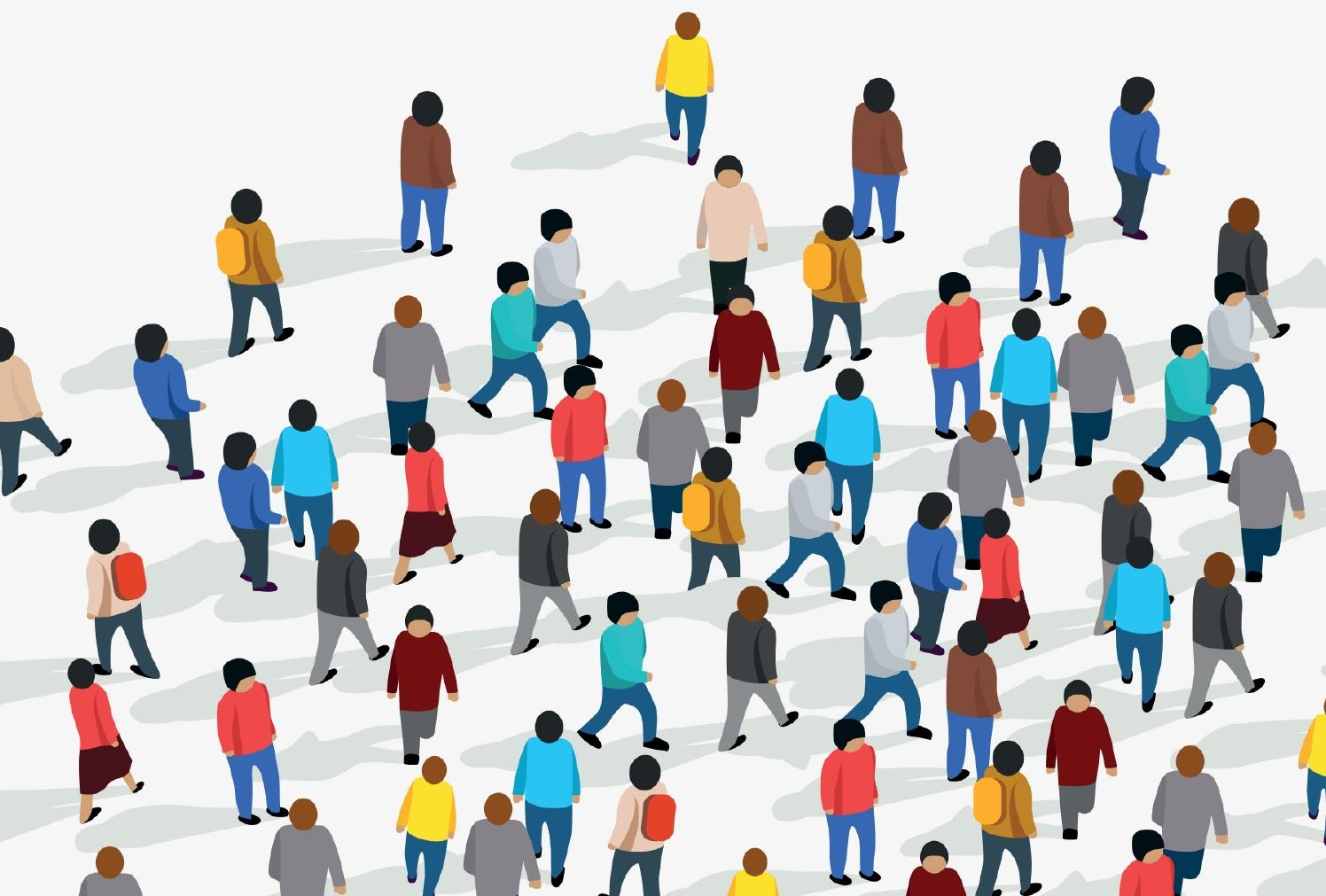


Ethnos Oblige 
This page intentionally left blank 


\section{Ethnos Oblige:Theory and Evidence}

BY

BANIYELME D. ZOOGAH

McMaster University, Canada

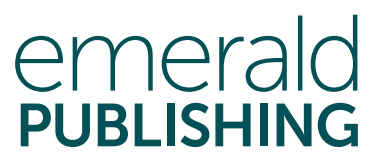

United Kingdom - North America - Japan - India - Malaysia - China 
Emerald Publishing Limited

Howard House, Wagon Lane, Bingley BD16 1WA, UK

First edition 2022

Copyright (C) 2022 Baniyelme D. Zoogah. Published under exclusive license by Emerald Publishing Limited.

\section{Reprints and permissions service}

Contact: permissions@emeraldinsight.com

No part of this book may be reproduced, stored in a retrieval system, transmitted in any form or by any means electronic, mechanical, photocopying, recording or otherwise without either the prior written permission of the publisher or a licence permitting restricted copying issued in the UK by The Copyright Licensing Agency and in the USA by The Copyright Clearance Center. Any opinions expressed in the chapters are those of the authors. Whilst Emerald makes every effort to ensure the quality and accuracy of its content, Emerald makes no representation implied or otherwise, as to the chapters' suitability and application and disclaims any warranties, express or implied, to their use.

British Library Cataloguing in Publication Data

A catalogue record for this book is available from the British Library

ISBN: 978-1-83867-516-5 (Print)

ISBN: 978-1-83867-515-8 (Online)

ISBN: 978-1-83867-517-2 (Epub) 
Dedicated to my spouse (Aleshia S. Zoogah) and children (Coniah A. Zoogah and Jalen Baniyelme Cloud Zoogah). Their love shielded me from life's thorns. 
This page intentionally left blank 


\section{Contents}

List of Figures and Tables ix

List of Abbreviations $x i$

About the Authors xiii

Foreword $x v$

Preface xvii

Acknowledgements xix

Introduction 1

Part I: Understanding Ethnos Oblige

$\begin{array}{lll}\text { Chapter } 1 \text { Context } & 15\end{array}$

Chapter 2 Concept 25

Part II: Elements of Ethnos Oblige

Chapter 3 Outcomes

$\begin{array}{lll}\text { Chapter } 4 \text { Drivers } & 77\end{array}$

$\begin{array}{llr}\text { Chapter } 5 & \text { Contingencies } & 89\end{array}$ 
viii Contents

\section{Part III: Studying Ethnos Oblige}

Chapter 6 Ethnos Oblige in Organizations 103

$\begin{array}{lll}\text { Chapter } 7 & \text { The Tribal Man } & 125\end{array}$

$\begin{array}{lll}\text { Chapter } 8 & \text { Perspectives } & 137\end{array}$

Appendices 153

References 165

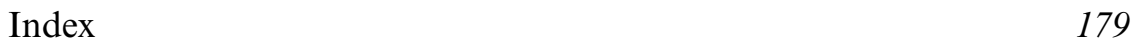




\section{List of Figures and Tables}

\section{Figures}

0.1 Typology of Tribe Concept 10

2.1 Schools of Ethnicity 32

2.2 Perspectives of Ethnic Obligation 37

2.3 General Model of Ethnic Obligation 41

2.4 Multilevel Model of Ethnic Obligation 44

2.5 Contingencies and Outcomes of Ethnic Obligation 46

3.1 Ladder of Causation and Ethnic Obligation 58

3.2 Standardized Trend of Ethnic Obligation Responses (2003-2012) 61

3.3 Interaction Plot of Dual Context moderation 62

3.4 Plot of Agency by Sector (Afrobarometer Study, 2004 - Round 2) 63

3.5 Structural Equation Model Results of Ethnic Obligation on $\begin{array}{ll}\text { Positive Organizational Behavior } & 74\end{array}$

4.1 Multilevel Determinant Model 78

5.1 Conceptual Model of Contingencies of Ethnic Obligation 91

5.2 Conceptual Models of Curvilinear Dynamics 92

5.3 Examples of Empirical Dynamics 94

5.4 Interaction Plot of Technology Moderation 98

8.1 Circumplex Model of Ethnic Obligation 139

8.2 Prediction of Ethnic Obligation as a Function of Identity Fusion and Malleability

\section{Tables}

3.1 Regression Results of Agency on Foreign Direct Investment (2012) 62

3.2 Interaction Results of Agency and Sector on Leader Performance Ratings (2012) 63

3.3 Regression Result of Agency on GDP per Capita (2008) 64

3.4 Interaction Results of Agency and Sector on GDP per Capita (2008) 64

3.5 Results of Agency Effect on Leader Performance and Management of the Economy (2002) 65

3.6 Correlations of Agency and Ethnic Group Outcomes 65

3.7 HLM Results of Agency (Leader Obligation) Effect on Ethnic Group Economic Conditions and Political Influence 
3.8 Multilevel Results of Economic Deprivation 70

3.9 (Individual Level) Correlations (Study 1) 72

3.10 Regression Results of Predictor of Experience of Ethnic Obligation 73

6.1 Ethnicity of Vice-Chancellors of the Three Major Universities in Ghana 107

6.2 Propositions on Tribe of Origin 122

7.1 Ethnicity Across Asian Countries by Period 127

8.1 Theory S and Theory E 145

8.2 Evaluation of Ethnos Oblige as a Theory 146 


\section{List of Abbreviations}

$\begin{array}{ll}\text { ADUM } & \text { Acquisition, Development, Utilization, and Maintenance } \\ \text { CAB } & \text { Cognitive, Affective, Behavioral system } \\ \text { KNUST } & \text { Kwame Nkrumah University of Science and Technology } \\ \text { KSAOs } & \text { Knowledge, Skills, Abilities and Other characteristics } \\ \text { NDC } & \text { National Democratic Congress } \\ \text { UCC } & \text { University of Cape Coast } \\ \text { UEP } & \text { Understand, Explain, and Predict functions of science } \\ \text { UHAS } & \text { University of Health and Allied Sciences }\end{array}$


This page intentionally left blank 


\section{About the Authors}

Baniyelme D. Zoogah (PhD, The Ohio State University) is Associate Professor of Management at the Williams College of Business, Xavier University, Cincinnati, Ohio, USA. He is founding Executive and current President of the Africa Academy of Management. His research generally focuses on development of competencies of individuals, groups, organizations, and nations. Currently, his research focuses on management, strategic followership, and corporate environmental sustainability issues in Africa and the world. He has published book chapters on Africa-centered Management, Green Management, Strategic Human Resources Management, and Methodology. He authored Strategic Followership: How Employees Contribute to Organizational Productivity and Theoretical Perspectives of Strategic Followership; edited Advancing Research Methodology in the African Context: Techniques, Methods, and Designs (Volume 10 of Research Methodology in Strategy and Management Series), and co-authored Managing Organizational Behaviour in the African Context. 
This page intentionally left blank 


\section{Foreword}

Social psychological research has demonstrated that the answer to the question, "Who am I?" is strongly influenced by the social groups one belongs to in a society. Pioneering social psychologist Henri Tajfel $(1974)^{1}$ captured this phenomenon in his theory of social identity. Social identity refers to an individual's knowledge of belonging to certain social groups that hold some emotional and value significance for him or her. Most interpretations of social identity theory dwell on its prediction of negative in-group/out-group dynamics while overlooking its positive effects. Belonging to and identifying with a social group enhances one's self-esteem and contributes to a positive identity. It can also provide collective solidarity among members of a social group.

Research has also shown that the ethnic group one belongs can significantly affect how one answers the question. Tribes are a major social identity group for people in Africa because of the size and diversity of ethnic groups. However, the answer to "Who am I?" is particularly complicated for people in Africa because of the long history of the denigration of the continent and negative portrayal of African ethnic groups as savage, uneducated tribes hopelessly mired in tribal conflict. The default conclusion is that belonging to an ethnic group or tribe is not desirable or beneficial. Ethnos Oblige: Theory and Evidence challenges this conclusion by making a convincing case of the benefits of tribal or ethnic identity in Africa. Zoogah achieves this goal by introducing the concept of ethnic obligation. Ethnic obligation is a cultural norm that regulates the interactions of ethnic group members with one another and with outsiders. A core element is the mutual obligation of members to be benevolent and agentic in their dealings with one another.

Ethnos Oblige: Theory and Evidence systematically builds a case for the benefits of tribes by first drawing upon history to understand the ontology of tribes and the effects of colonialism on the tribal structure of the continent. According to Zoogah, what seems to be missed by those who hold negative views about tribes is that precolonial Africa was thriving economically and socially, well on its way to modernity before the brutal intrusion of colonialism. Colonizers disrupted Africa's development, reconfigured tribal micro-nations (tribes) replacing them with arbitrary macro-nations, discouraged tribal affiliations, and fueled

${ }^{1}$ Tajfel, H. (1974). Social identity and intergroup behaviour. Social Science Information, 13(2), 65-93. 
tribal conflict to achieve their goals. Thus, much of the contemporary ethnic conflict in Africa today has its roots in colonial practices. Zoogah also points to the survival of tribal identities among Africans despite postindependence efforts to suppress them in the pursuit of nation-building. In fact, many have argued that tribes hinder nation-building in Africa and contribute to interethnic conflict and economic stagnation. It is this negativity about tribes and ethnic groups in Africa that Ethnos Oblige: Theory and Evidence tackles head-on.

Building upon the ontological and colonial history of tribes in Africa, Zoogah then shares the results of empirical research that tests the effects of tribes on individuals and organizations. What makes his empirical work so convincing is that he does not posit a simple linear relationship between tribes and positive outcomes. Instead, he explores the antecedents, contingencies, and dynamics of the relationship. This careful empirical work lays the foundation for recommendations on how obligations of individuals to their tribes or ethnic groups determine positive (and negative) outcomes for themselves, others, organizations, and ultimately society.

Ethnos Oblige: Theory and Evidence makes an original and influential contribution to building the insufficient knowledge about ethnic group behavior in Africa and its importance to employee behavior and building effective organizations in Africa. This book is foundational reading for anyone interested in making contributions to building management theory relevant to Africa. However, ethnic obligation is also relevant to other parts of the world where ethnic groups are salient. Thus, this book is an invaluable resource for understanding how leaders and managers can leverage strong ethnic affiliations to enhance individual, group, organizational, and national performance beyond the default assumption of adverse effects. It also provides a research agenda for further exploration of ethnicity in Africa and the world.

Stella M. Nkomo

Pretoria, South Africa 


\section{Preface}

The extant view of the concept of tribe and ethnicity is negative. It has been devalued so much that it is used derogatively and in an ascribed manner. One reason is the increasing drive to promote the macro-nation (i.e., state) over the micro-nation (i.e., tribe or ethnic group). Another reason or disguise is the socalled enlightenment which advocates for fair treatment toward all others rather than specifically toward ethnic group members. I believe the denigration of the concept of tribe is wrong, ill-informed, and misunderstood. My belief fits with others who have advocated a positive view of ethnicity and the right of micronations. It is wrong because the negative attributes are by individuals who lack the ecological validity (they have either not lived in tribes or being members of tribes). They are ill-informed because their views are etic. They are outsiders who observe the tribe and make attributions that have no validity. They are misunderstood because their views are not based on nomological essence. The writers seem not to have clear conception of what being a tribal member entails or means. To disparage, denigrate, or ask for its abolishment is to ask a Brit not to be a Brit or Chinese not to be a Chinese or a Jew not to be a Jew or a Japanese not to be a Japanese. Being a Brit, Chinese, Jew, Japanese, etc. is ontological. It comes with obligations.

The purpose of this book therefore is to help improve that understanding. I am discussing how obligations of individuals to their tribes or ethnic groups determine positive (and negative) outcomes to those individuals, their peers, departments, organizations, and even society. One of the functions of science is to explain phenomena. In that regard, explaining ethnic obligation helps us to understand the phenomena particularly in contexts with salient ethnicities. When scholars study the drivers, antecedents, and explanatory factors undergirding ethnic obligations, they generate insight for managers to establish mechanisms that either magnify the positive effects or control the negative effects. Insight from studies of the dynamics of ethnic obligation is also helpful to organizations. Last, effect studies enable managers to sustain the factors or mechanisms that led to the positive outcomes or muffled the negative ones.

So, my goal for this book is twofold. First, I want to encourage more research in ethnic obligation. Scholars in societies with salient ethnicities have a responsibility to improve their societies by examining phenomena operating therein. Through scientific studies, they can uncover insight that helps them to defend, promote, uphold, or support their ontology. It becomes an opportunity for them to rebuff destructive criticisms particularly by those who do not understand 
tribes or ethnic groups. Second, I want to argue that managers in contexts with salient ethnicities have to dive into the deepest recesses of their creative genius to device operational and strategic mechanisms that make ethnicity beneficial. The ability of managers to understand, explain, and predict ethnic obligation enables them to effectively manage the behaviors of their employees. Both goals are functional. For both scholars and managers, tribal affiliation should not be "the elephant in the room" or the "hundred-pound gorilla." There is nothing to be ashamed about being a member of a tribe. And there is nothing wrong with being a member of a tribe. What is wrong is weaponizing the tribe to do evil. This book is not intended to be a poison-spear in the quiver of scholars or managers of the latter category. Instead, it is to be a recipe for progress; a means to lock in the benefits of tribal affiliation. 


\section{Acknowledgements}

I am indebted to several people whose humanity directly or indirectly enabled me to complete this book. First, I thank my family. Aleshia, Coniah, and Jalen have been tremendous. They allowed me to spend more time on this book. I also appreciate the "bouncer," Dr Phyllis Keys, who allowed me to bounce some ideas off her for feedback. Her comments were invaluable. Some other special people who supported me are Janice Walker, Tom Clark, Amit Sen, Mina Lee, Thilini Ariyachandra, and Lynda Kilbourne, who in varied ways lowered the temperature when the furnace was very hot. I continue to thank Fr Ugo Nacciarone, sj, for his support since 1985, Terence Charlton, sj, as well as Robert and Margaret Cloud, whose magnanimity transformed the trajectory of my life. Along the way, some other special people were influential. They are Peter Bycio, Jim Walsh, and Stella Nkomo. To them I owe much. I also thank my brothers and sisters for their support. My gratitude to all my siblings. Interactions with them unearthed some ideas in this book. All other friends who in indescribable ways assisted me deserve to be acknowledged. To them I say, thank you! To the micro-nations of Africa, I echo Jomo Kenyatta's admonishment ${ }^{2}$ : beware of the fangs of allochthons which are digging deeper into your neck to choke out your vitality.

\footnotetext{
${ }^{2}$ The First President of Kenya. See his book, Facing Mount Kenya (p. 306), for this admonishment.
} 